\title{
Ethnicity Revivals in Indonesian Local Political Dynamics: A Legal Pluralism Analysis
}

\author{
Sukri $^{1}$, Hamzah Halim ${ }^{2}$, Alwi Jaya ${ }^{3}$ \\ (sukripolitik@gmail.com ${ }^{1}$, anchapunggawa@gmail.com ${ }^{2}$, sukritamma@yahoo.com ${ }^{3}$ ) \\ Hasanuddin University, Faculty of Social and Political Science, Jl. Perintis Kemerdekaan Km. 10 \\ Tamalanrea, Makassar, Indonesia ${ }^{1}$ \\ Hasanuddin University, Faculty of Law, Jl. Perintis Kemerdekaan Km. 10 Tamalanrea, Makassar, \\ Indonesia $^{2}$ \\ The Lapatau School of Law, Jl. Bajoe, Bone, Indonesia ${ }^{3}$
}

\begin{abstract}
This paper aims to analyze the phenomena of democracy in terms of local election in the Toraja area related to the existences of the toraja ethnic group as the majority and their indigeneity. It tends not simply as the way to proof the "people rule" as it is usually knowing only by people in related to the democracy that is legalized by the state regulation. That democracy event is an opportunity for their customary guidance existences that makes this situation as the "legal pluralism" arena. That situation should be viewed as a critical discourse between the general idea of democracy that formalized by the state and the local values. Hence it seems that presences of both laws will influence the Toraja's form of democracy that shows dynamics of the state formal regulation and the customary law existences.
\end{abstract}

Keywords: Local Election, Legal pluralism, Toraja Ethnic, Adat

\section{Introduction}

When the ruler regime of Indonesia, Suharto proclaimed to resign his position In May 1998 as the president the country Iseems has started its way to be democratic country. After experiencing more than 30 years authoritarian and centralize authority, this country began its effort to be a new democratic country. Many activities appear as effort to switching Indonesian social and political system thru democratization that also impacts in most regions in Indonesia. This era provided democracy as an obligation ands best way to manage Indonesian people. Democracy is become the most prominent system for Indonesia.

Many policies released by the government to support the effort to be democratic society. In terms of local people, when the idea of democracy came to their lives as the part of government desires, it seems to be received as a good thing as with what the government's opinion about it. But some facts from the local people's experience on democracy become the prominent think to be embodied. Based on that intention, the presence of two policies, the regional autonomy policy and the local election, becomes crucial.

Thru the spirit of democratization, there are many opportunities and spaces for the people as 
the important element of democracy. Consequently, for community like the indigenous people that have their own rules and requirements to choose a leader, the election then become an event for two laws, the formal and the customary law. It makes the election occurred as a "legal pluralism" condition. It happens due to there are two fundamental laws meet in the democratic event that asked similar obedience. As one of indigenous people in Indonesia, their experience should be viewed as the indigenous commuity reacting to the general term of democracy that is institutionalized thru state regulations.

\section{Research Method}

Analysis of this paper is based on field research data. The research was conducted in the North Toraja District, Province of South Slawesi, Indonesia. Based on the qualitative method thru a case study, the research aims to show the experience of an indigenous people namely the Toraja Ethnic Group related to local election ans existence of their customary laws called as adat. Thru various in-depth interview and secunder data collecting process this research showed how this ethnic group has experience a unique situation under the legal pluralism when two fundamental laws occur in the same time during the local election. It was creating a unique pattern of how the ethnic group still respect to the formal law while also obey their adat.

\section{Result and Discussion}

\subsection{Legal Pluralism}

The legal pluralism is based on two key words "Legal" and "Pural". The first word usually associated to something that legally established by a statute or regulation. The word "Plural" is usually contrasted to a single form or something that varies or more than one aspect. It means, legal pluralism defines as situation which two or more "laws" that legally exist interact with each other [1]. The condition is usually focus on a particular community that particularly interested in the transfer law process between cultures. The interrelation between laws and cultures are usually associated with the formal law by the state and the local custom that usually exist and regulate a particular community. This condition will usually occur in context of certain community that has particular legal system or norms based on common beliefs and common values that mostly part of the community uniqueness social identity [2].

There are two types of legal pluralism, the weak and the strong condition. The first condition happens when there is a command of different legal institutions against different groups in a particular society through a normative order of a court or legal institution center. It can be seen as "technique of governance" that exists only on state law that means the presence of the non-state 
law will depend on recognition of the central government. The strong pluralism exists in existence of normative rules; regardless of its origin that exists together and has mutual respect with others in the situation that is unavoidable in the rules of the universe [3].

Thru the approach of legal pluralism, the objective context of each community is an important thing. It makes the "social fact of legal pluralism" (sflp) becom the fundamental aspect of this view. It is based on the reasons that (a) it is not limited to nation states, countries, or society understood as a unit; (b) it extends the concept of the law to include at least some types of nonstate law; (c) it adopts the stand point of legal observers that are beyond them, but take into account the point of view of the internals of the citizens, lawmakers, judges and others [4].

The "sflp" could be built upon contexts due to the anthropological and socio-legal is studies based on the understanding of local knowledge as an important aspect. It means, this approach concern to interaction among various norms or orders that must be admitted equally. Therefore, the rule of law as people behavior patron is no longer seen as something that refers to the formal legal state, uniformity for all persons, exclusive of all other law, and administered by a set of state institutions but also will refer to the context of local values that regulate how local community should behave [5]. In this sense, all law could be defined as "law" and must be admitted equally. It is usually occurred especially within certain community that has other law system beyond the formal one by the state. In Indonesian context, there are some community's as like as the indigenous people that usually live ordinary with various kinds laws in their context [6]. Therefore, although there is an attempt to generalize the meaning of legal pluralism, however there is an idea that tends to agree that this understanding presupposes of non- state of legal law conception. It emphasizes on how people establish themselves as the subject in relation to the existence of some laws in the social practices, power relations, institutions and political law, formal law, the rule of non-formal normative orders etc. This condition provides some important things or events within particular community will possibly regulated or related to those laws present. One of the important events within community life is the local election. It is important due to it is proclaimed as important democracy event that should respect to the variety norm and value of people.

Within various local elections in, people are the important aspect due to the direct election mechanism. It makes people's preference and voting behavious will determine the event result. Due to in the context of indigenous people usually has common system of law as like as customary law that beyond the state regulation, they will be faced two laws at the same time. Since process to select a leader usually a fundamental event for these communities then the present of customary laws is important. Usually the customary law has own standard of requirements and process that respected by its people. As subject of variety laws then makes people should behave suitable within those two, formal and customary laws. It makes the people usually use both of laws based on their interest thru the laws. When they need to fullfil the formal requirements then the formal law will be followed, but when the unique of local context should be fulfilled then the other law 
will present as the main direction. It makes the legal pluralism analysis usually related to present of those laws as the main pattern of people behavior in the event.

\subsection{Local Election and the Present of Two Fundamental Laws for the Toraja Ethnic Group}

The North Toraja local election in 2015 was became unique phenomena related to how an indigenous people behave within present of two laws that equally important for their context. During the event, there were two important issues indicated influencing of adat as locally fundamental pattern to select a leader. The issues were related to the appropriate candidate and how to win the rivalry by utilizing the torajas respect to their adat where also known as aluk. As the majority voters due to its amount number of people, those issues were important for the election winner.

Actually, based on the state regulation, all people have rights as the voter or to be voted as candidate as far as they meet the requirements. Generally, the formal requirements regulated thru the formal law include: believes in one God; faithfully follow the state ideology and the constitution; occupy at least secondary school and/or equivalent educational level; minimal age is 30 (thirty) years old; Health condition physically and mentally; never been sentenced to imprisonment five years or more; not being deprived of their right to vote under a court decision, which has obtained permanent legal force; known by the people in the region; submit a list of personal wealth and willing to be announced; does not currently have a mortgage debt; he/she is not bankrupt by a court decision that has obtained permanent legal force; never committed a violation of act; have a Taxpayer Identification Number; submit a complete curriculum vitae; have never served as regional head or deputy head of the region during the two consecutive terms in the same position; not in status as the acting head of the region. All of those formal requirements aimed for all individu who want to be a candidate in the local election.

As implementation democracy, those legal requirements basically were present as formal guarantee of equality for all people to be as candidate or to votes. If candidates aim to win then they should win majority voters. It means candidates should placed themselves appropriately within the voters. Since voters have their own reasons to vote, candidates should match to the voter's preference. Since most voters usually respect to their local context as fundamental preferences then candidate should fix to the local common requirements. For the toraja people, in creation of the candidate's appropriateness, it should be to the adat direction. As its consequences, the local election was deeply influencing by adat related two main discourses. First, the candidates were not only must fit to the formal requirements but also the adat requirements, and candidates then not only should have capability, wisely, and wealthy aspect but also must be a noble descendant. Consequently, only the aristocrat person has opportunity to be candidate. At the same time, the nobility requirement had eliminated the non-noble people opportunity to be the leader. It makes the democratic competition to be utilized by the noble thru their privilege based on the 
adat. Secondly, the candidates should able to influence people by utilizing some important social events that related to their local common value. It made the result of the local election actually deeply respect and under the adat circumsetences even it was happened thru formal regulations.

Various facts from the local election in North Toraja 2015 has confirm that the local election was deeply influenced the toraja common cultural values. It was as consequences of their ethnicity's identity. Even actually it is non-political aspect but due to it was as the toraja's crucial preference to vote then it becomes important. It figures out how the event where regulated thru the formal laws was deeply influenced by various informal aspects based on the customary laws. It makes the torajas people to behave appropriately within those two laws. Presence of those laws and why that local election involved those laws are actually related to legitimation of the result and people's support after election. In context of toraja region, due to this ethnic group is majority and also claim the area as their sacred land, a leader should have not only formal legitimation based on the formal laws but also the informal legitimation thru the adat.

Actually, as long as all formal regulation has been followed during the local election, the event and its result formally legitimate. But, since the event take place in the sacred land of the toraja ethnic group that has its own common then the leader should be fix to the majority community common laws, the adat. When those are fulfilled, the chosen leader will be received respect from the people to lead people in this unique land thru two legitimation, formal law and adat [7]. That condition actually makes the local election event as a process of a candidate to be leader in the toraja area based on both legitimation sources. Since most of the torajas used those two laws to decide their choice and it seems like a mandatory aspect, then the legitimacy by people to establish democracy in the toraja context will be related to existences o those two prominent laws.

\section{Conclusion}

Phenomena from the toraja ethnic group experiences to vote formal leader in their region thru democratic way tends to produce a unique pattern of their voting behaviour. It because there were two fundamental laws involved in same event, the adat as customary law and the formal laws. This condition was happening due to the return of ethnicity and its unique local value returns as prominent order in the political field. It made the Toraja ethnic group as an indigenous people had provided unique experiences to behave politically during the local election under two fundamental laws.

The facts from the North Toraja local election 2015, it confirmed that dynamics the election should be seen as a unique community way for the coming of democracy in their live. Although the local election is regulated thru formal laws but the existence of aluk made the torajas to find a suitable way to run between the two laws. It happened due to the local election was not the only the formal event to choose the regional government leader. For the torajas, that event is also as the 
rivalry arena of the noble families as well as the way to proof the toraja's honour. Therefore, it was part of logical pattern when most of the process during the local election was influenced by the torajas' adat. It means presence of the two laws in that event made the local election to become the real pictures of how the toraja ethnic group reacts to the formality of the state as the toraja ethnic group did.

In the end, since a leader is formed thru uniquely way in the legal pluralism condition of the torajas, then they must stand in those two sides. For this etnic group, the leader is always expected as the formal and informal leader as well. In this situation, a leader will be asked to assure itself suitable with those to guarantee their presence of authority and policy to be successful.

\section{References}

[1] Lakin, K.: Legal Pluralism in Archaic Greece. Princeton/Stanford Working Papers in Classics Paper. pp. 1-40. (2005)

[2] Benda-Beckmann, Frans von. : Citizens, Strangers, and Indigenous People Multiple Constructions and Concequences of Rights, Resources and People. Presented at 13th IUAES International Conference. pp. 1-28. (1993)

[3] Griffiths, J. : What is Legal Pluralism. Journal of Legal Pluralism. Nr. 24. (1986).

[4] Lakin, K. : Legal Pluralism in Archaic Greece. Princeton/Stanford Working Papers in Classics Paper. pp. 1-40. (2005)

[5] Lakin, K. : Legal Pluralism in Archaic Greece. Princeton/Stanford Working Papers in Classics Paper. pp. 1-40. (2005)

[6] Benda-Beckmann, Frans von. : Citizens, Strangers, and Indigenous People: Multiple Constructions and Concequences of Rights, Resources and People. Presented at 13th IUAES International Conference. pp. 1-28. (1993)

[7] Yunus, R. and Tamma, S. : Importance of Cultural Legitimacy to the Local Government in Indonesian Democracy. Bisnis \& Birokrasi Journal., Vol 21. pp. 27-34 (2014) 